\title{
Pendampingan Sekolah Online Siswa SD Melalui Kegiatan SIPUNG (Sekolah Ing Kampung) Pada Masa Pandemi Covid 19 Sebagai Solusi Mengatasi Pendidikan Di Desa Nguling- Pasuruan
}

\author{
Nurin Nazlah, Wahyu Djoko Sulistyo \\ 1Universitas Negeri Malang \\ E-mail: nurinnazlah131@gmail.com
}

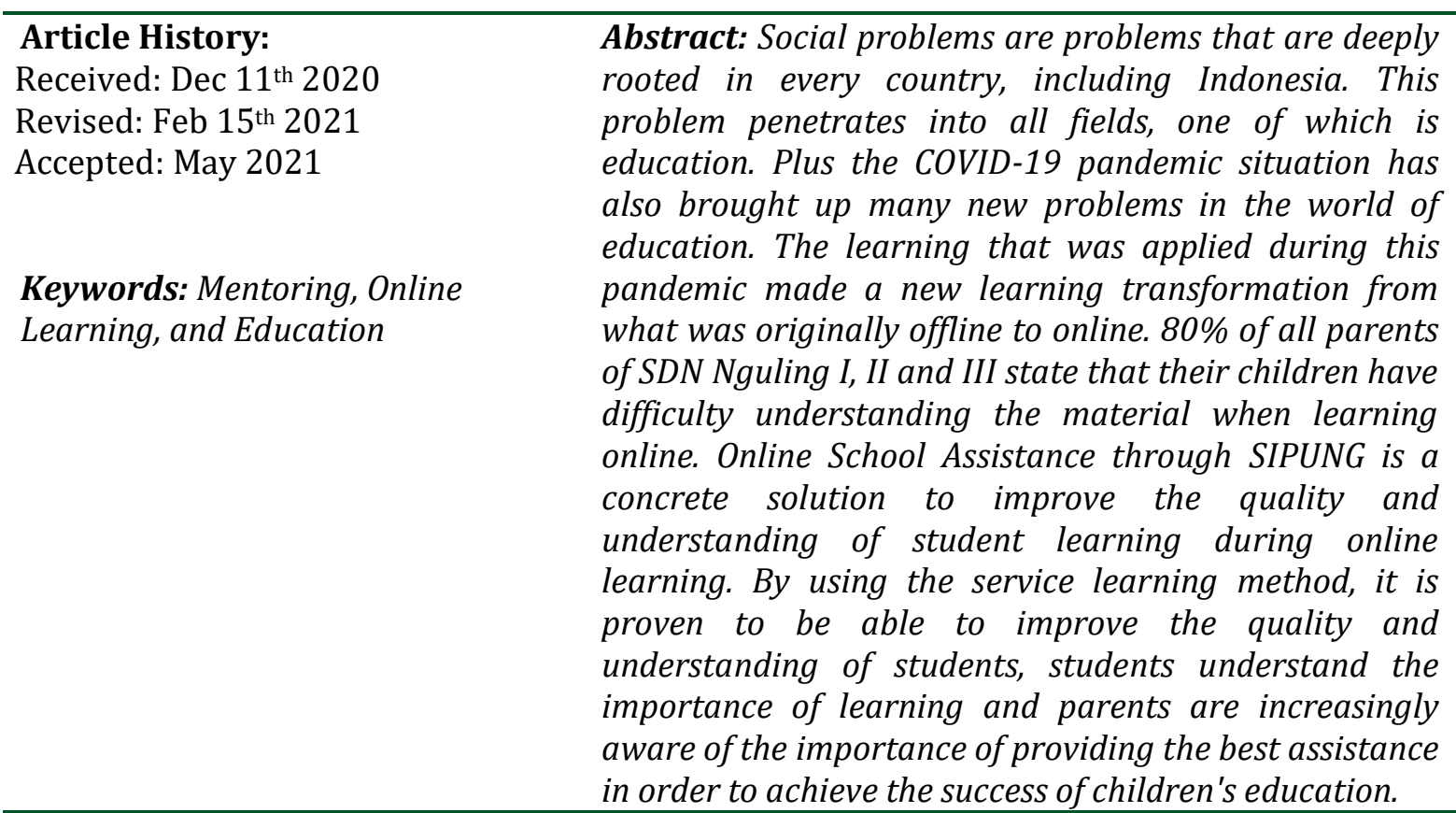

\section{Pendahuluan}

Dinamika pendidikan di Indonesia pada dasarnya tidak dapat dilepaskan dari berbagai permasalahan. Permasalahan dalam dunia pendidikan menjadi salah satu dari sekian permasalahan sosial yang ada ditengah masyarakat. Ditambah dengan kondisi pandemi seperti saat ini, permasalahan sosial yang terjadi semakin banyak dan memperparah keadaan. Seluruh elemen merasakan dampak dari COVID-19 salah satunya adalah elemen pendidikan Indonesia. ${ }^{1}$ Pendidikan dalam sejarah peradaban manusia

${ }^{1}$ Rizqon Halal Syah Aji, “Dampak COVID-19 Pada Pendidikan Di Indonesia: Sekolah, Keterampilan, Dan Proses Pembelajaran," Salam: Jurnal Sosial dan Budaya Syar-i.(7) 5 (2020): 395-402; Beby Masitho Batubara, "The Problems of the World of Education in the Middle of the Covid-19 Pandemic," Budapest International Research and Critics Institute (BIRCI-Journal): Humanities and Social Sciences 4, no. 1 (2021): 450-457. 
merupakan salah satu komponen kehidupan yang paling mendasar. Pendidikan merupakan pondasi pertama untuk membangun peradaban sebuah bangsa. Hal tersebut dibuktikan oleh negara-negara maju yang memiliki ilmu pengetahuan dan teknologi yang didukung oleh kualitas pendidikan yang kokoh. ${ }^{2}$

Dalam UU RI No 20 Tahun 2003 pasal 3 ayat 1 pendidikan nasional berfungsi mengembangkan kemampuan dan membentuk watak serta peradaban bangsa yang bermartabat dalam rangka mencerdaskan kehidupan bangsa, bertujuan untuk berkembangnya potensi peserta didik agar menjadi manusia yang beriman dan bertakwa kepada Tuhan Yang Maha Esa, berakhlak mulia, sehat, berilmu, cakap, kreatif, mandiri, dan menjadi warga negara yang demokratis serta bertanggung jawab. ${ }^{3}$ Fungsi dan tujuan yang telah dijelaskan dalam pasal tersebut mengarah kepada peningkatan kualitas bangsa. Kualitas bangsa ini bersumber sumber daya manusia yang ada pada suatu negara. Dengan adanya pendidikan yang baik maka terciptalah sumber daya yang baik.

Pendidikan menjadi salah satu faktor suatu negara berkembang kearah yang lebih baik. Jika ingin melihat keadaan suatu negara maka lihatlah pendidikan yang ada didalamnya. Pendidikan akan menciptakan bibit-bibit unggul sebagai generasi muda berkualitas. Generasi muda inilah yang nantinya akan memimpin negara ini. Maka sangatlah penting pendidikan yang baik di dalam suatu negara. Karena berdiri tegak atau tidaknya suatu negara ditentukan oleh pendidikan yang mencetak generasi muda tersebut. ${ }^{4}$ Mengingat kondisi saat ini adalah pandemi COVID-19 khusunya di daerah Kabupaten Pasuruan yang sempat berada di zona oranye pada tanggal 28 September $2020 .^{5}$ Hal ini mengakibatkan seluruh sekolah mengganti kegiatan belajarnya dengan pembelajaran online atau yang lebih dikenal dengan sebutan daring. ${ }^{6}$ Pembelajaran daring ini dimulai dari dikeluarnya surat edaran Menteri Pendidikan dan Kebudayaan nomor 4 tentang pelaksana kebijakan pendidikan dalam masa darurat penyebaran COVID-19 yang berisi himbauan belajar dirumah. ${ }^{7}$

Daring merupakan sebuah metode belajar interaktif yang menggunakan internet

2 Stefanus M. Marbun, S. Th, and M. PdK, Psikologi Pendidikan (Uwais Inspirasi Indonesia, 2018).

3 PRESIDEN REPUBLIK INDONESIA, “Undang-Undang Republik Indonesia Nomor 20 Tahun 2003 Tentang Sistem Pendidikan Nasional” (2006).

4 Muhardi Muhardi, "Kontribusi Pendidikan Dalam Meningkatkan Kualitas Bangsa Indonesia," Mimbar: Jurnal Sosial dan Pembangunan 20, no. 4 (2004): 478-492.

${ }^{5}$ pemkab pasuruan, "Kabupaten Pasuruan Kembali Berstatus Zona Oranye Covid-19 | Situs Resmi Pemerintah Kabupaten Pasuruan," last modified 2020, accessed June 8, 2021, https://www.pasuruankab.go.id/berita-5943-kabupaten-pasuruan-kembali-berstatus-zona-oranyecovid-19.html.

${ }^{6}$ Awal Nopriyanto Bahasoan et al., "Effectiveness of Online Learning in Pandemic COVID-19," International Journal of Science, Technology \& Management 1, no. 2 (2020): 100-106; Mustakim Mustakim, "Efektivitas Pembelajaran Daring Menggunakan Media Online Selama Pandemi Covid-19 Pada Mata Pelajaran Matematika," Al asma: Journal of Islamic Education 2, no. 1 (2020): 1-12.

7 MENTERI PENDIDIKAN DAN KEBUDAYAAN and REPUBLIK INDONESIA, "Surat Edaran Nomor 4 Tahun 2020 Tentang Pelaksanaan Kebijakan Pendidikan Dalam Masa Darurat Penyebaran Coronavirus Disease (COVID-19)" (2020). 
dan LSM (Internet dan Learning Manajemen System). Pembelajaran daring ini didukung dengan memanfaatkan aplikasi seperti Google Meet, Google Drive, Zoom dan yang lainnya. ${ }^{8}$ Kegiatan selama pembelajaran daring ini adalah kelas online dan webinar yang seluruhnya menggunakan akses internet. ${ }^{9}$ Berdasarkan hasil observasi penulis, hal ini juga serupa dengan dilakukan oleh para pendidik di SDN Nguling 1, SDN Nguling 2 dan SDN Nguling 3 yang saat ini telah menggunakan pembelajaran daring kelas online dengan memanfaatkan WhatsApp Group. Para guru SD di Desa Nguling memberikan materi dan tugas melalui WhatsApp Group.

Dalam kondisi ini pelajar dituntut untuk tetap belajar secara individu dengan materi yang telah diberikan oleh guru sehingga banyak pelajar yang sangat kesulitan dalam menangkap dan memahami materi yang diberikan. Masa pandemi adalah masa dimana semua orang dihadapkan dengan kegiatan serta kebiasaan baru. Semua orang dituntut untuk bisa survive serta beradaptasi dengan keadaan yang ada. Salah satu nya adalah seorang siswa. Siswa dihadapkan dengan banyak keadaan yang menutut mereka harus berdamai, salah satunya adalah belajar. Di pembelajaran online siswa sangat kesulitan dalam memahami materi yang diberikan oleh gurunya, bahkan banyak diantara siswa lebih memilih untuk bermain. Hal ini sejalan dengan observasi yang dilakukan penulis di Desa Nguling bahwa di jam-jam yang seharusnya anak belajar dirumah melaksanakan pembelajaran daring ternyata tidak melakukan akan tetapi bermain bersama teman-temannya. Selain itu berdasarkan hasil angket yang dibagikan kepada para orang tua menyatakan bahwa tugas yang diberikan oleh guru yang mengerjakan adalah orang tua.

Usia yang masih kecil dan keinginan bermain yang sangat tinggi membuat mereka benar-benar minim belajar saat pembelajaran online. Jika hal ini berlangsung selama berbulan-bulan dan bertahun-tahun dalam rentang waktu yang lama bisa dibayangkan bagaimana nasib anak bangsa kedepan. Kemampuan literasi mereka sangat kurang dan banyak hal lainnya yang mengkhawtirkan. Selama pembelajaran daring ini maka perlu adanya pendampingan belajar. Hal ini sejalan dengan hasil penelitian yang dilakukan oleh Handayani, Khasanah dan Yosintha (2020) bahwa sangat penting kegiatan pendampingan belajar, karena kegiatan ini dapat membuat siswa menjadi lebih paham dengan materi yang diajarkan oleh guru. Siswa juga merasa lebih terpacu untuk belajar seperti di kelas. Selain itu, kegiatan pendampingan belajar ini juga meringankan tugas orang tua dalam membimbing belajar anaknya di rumah. ${ }^{10}$

${ }^{8}$ Arley Henry and Teresa Shellenbarger, "To Zoom or Not to Zoom? Choosing a Videoconferencing Platform," Nurse Author \& Editor 30, no. 4 (2020): 3.

9 Lidia Simanihuruk et al., E-Learning: Implementasi, Strategi Dan Inovasinya (Yayasan Kita Menulis, 2019).

10 Tri Handayani, Hariyani Nur Khasanah, and Rolisda Yoshinta, "Pendampingan Belajar Di Rumah Bagi Siswa Sekolah Dasar Terdampak Covid-19," ABDIPRAJA (Jurnal Pengabdian kepada Masyarakat) 1, no. 1 (2020): 107-115. 
Berdasarkan permasalahan tersebut maka perlu adanya solusi konkrit dan sebagai pijakan awal untuk mengatasi serta mengurangi hal-hal yang tidak diinginkan di masa mendatang. Salah satu solusi konkrit yang dapat dilakukan adalah dengan memberikan pendampingan sekolah online siswa SD melalui kegiatan SIPUNG (Sekolah Ing Kampung) pada masa pandemi Covid-19. Tujuan utama adanya pendampingan ini adalah untuk membantu para siswa memahami materi yang diberikan guru selama pembelajaran daring. Selain itu hal ini juga untuk membantu orang tua dalam mengatasi kesulitan saat mendampingi anak belajar dirumah. Kegiatan ini juga untuk menumbuhkan suasana belajar yang menyenangkan.

\section{Metode}

Program pendampingan melalui SIPUNG ini menggunakan metode service learning. Service learning adalah sebuah pendekatan pengajaran dengan menggabungkan tujuan akademik serta upaya memberikan kesadaran dalam memecahkan kejadian atau persoalan yang ada di masyarakat secara langsung. Service learning ini mengintegrasikan capaian akademik dan karakter dari peserta didik melalui kelas ataupun lapangan secara langsung. Dengan pendekatan service learning ini, pengajar dapat menghubungkan mengenai teori materi yang diberikan di kelas dengan kondisi nyata yang ada dan dihadapi oleh masyarakat. ${ }^{11}$ Metode dengan pendekatan service learning ini terdiri dari 3 tahap yakni persiapan, pelayanan, dan refleksi. ${ }^{12}$

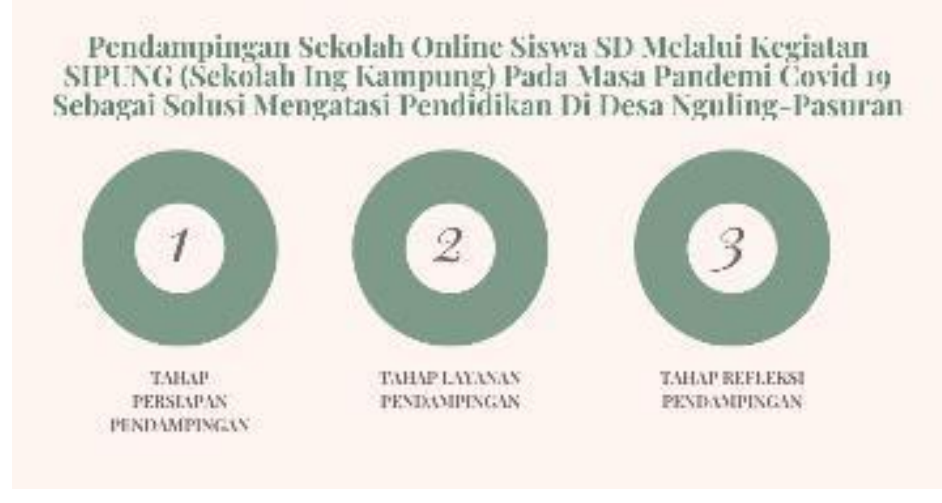

Gambar 1. Tahapan Service Learning Pendampingan Sekolah Online Siswa SD Melalui Kegiatan SIPUNG

Pada tahap pertama yakni persiapan, penulis melakukan koordinasi dengan para

\footnotetext{
${ }^{11}$ Endah Setyowati and Alviani Permata, "Service Learning: Mengintegrasikan Tujuan Akademik Dan Pendidikan Karakter Peserta Didik Melalui Pengabdian Kepada Masyarakat," Bakti Budaya: Jurnal Pengabdian kepada Masyarakat 1, no. 2 (2018): 143; Peter Felten and Patti H. Clayton, "Service-Learning," New directions for teaching and learning 2011, no. 128 (2011): 75-84.

12 Muh Barid Nizarudin Wajdi et al., "Pendampingan Redesign Pembelajaran Masa Pandemi Covid19 Bagi Tenaga Pendidik Di Lembaga Pendidikan Berbasis Pesantren Di Jawa Timur," Engagement: Jurnal Pengabdian Kepada Masyarakat 4, no. 1 (2020): 266-277.
} 
orang tua siswa untuk memetakan permasalahan yang dihadapi oleh para orang tua dirumah selama pembelajaran daring. Selanjutnya adalah membuat proposal mini dan koordinasi dengan Kepala Sekolah SDN I, II, III Nguling dan Kepala Desa Nguling. Tahap kedua yakni pelayanan. Dalam tahap ini penulis melakukan pendampingan sekolah online siswa SD melalui kegiatan SIPUNG (Sekolah Ing Kampung). Pendampingan ini terbagi menjadi tiga kegiatan yakni (1) Perkenalan, (2) Pembentukan kelompok belajar dan (3) Pendalaman. Tahap ketiga adalah refleksi. Pada tahap ini dilakukan evaluasi dari segala proses pendampingan yang telah dilaksanakan. Adapun waktu pendampingan dilakukan pada bulan September-November 2020.

\section{Hasil}

Virus COVID-19 yang terjadi saat ini telah memberikan dampak yang sangat besar di bidang pendidikan khusunya transformasi budaya belajar dari offline menjadi online. Pembelajaran online ini dimulai dari dikeluarnya surat edaran menteri pendidikan dan kebudayaan nomor 4 tentang pelaksana kebijakan pendidikan dalam masa darurat penyebaran COVID-19 yang berisi himbauan belajar dirumah, salah satu bagi Sekolah Dasar (SD). Pembelajaran Daring ini menjadi sesuatu yang baru bagi siswa SDN Nguling I, II, dan III. Hal ini meyebabkan banyak permasalahan yang terjadi, salah satunya terabaikannya pembelajaran siswa dirumah.

Usia siswa sekolah dasar yang berada di rentan usia 7-12 adalah usia yang masih kecil, ditambah dengan keinginan bermain yang semakin tinggi membuat para siswa minim belajar. Dengan adanya hal ini maka selama pembelajaran daring perlu adanya pendampingan belajar. Berdasarkan penjelasan tersebut pendampingan sekolah online kepada siswa SD melalui kegiatan SIPUNG (Sekolah Ing Kampung) pada masa pandemi COVID-19 sebagai solusi mengatasi pendidikan di Desa Nguling-Pasuran menjadi penting untuk dilaksanakan.

\section{Tahap Persiapan Pendampingan}

Langkah awal yang dilakukan penulis adalah melakukan koordinasi dengan para orang tua siswa. Koordinasi ini dilakukan untuk memetakan permasalahan yang dihadapi oleh para orang tua dirumah selama pembelajaran daring. Orang tua siswa disini berperan sebagai perwakilan objek dari siswa. Selanjutnya penulis memberikan angket kepada orang tua siswa SDN Nguling I, II dan III. Berikut merupakan hasil dari angket para orang tua:

Tabel 1. Hasil Angket Pendampingan Belajar Orang Tua di Rumah

\begin{tabular}{cccc}
\hline No. & Pernyataan & \multicolumn{2}{c}{ Jawaban } \\
\cline { 3 - 4 } & & Ya & Tidak \\
\hline 1. & Anak saya melakukan pembelajaran daring & $100 \%$ & $0 \%$ \\
\hline
\end{tabular}




\begin{tabular}{rlcc}
\hline 2. & $\begin{array}{l}\text { Anak saya mengalami kesulitan memahami } \\
\text { materi saat pembelajaran daring }\end{array}$ & $80 \%$ & $20 \%$ \\
\hline 3. & $\begin{array}{l}\text { Anak saya sering bermain saat pembelajaran } \\
\text { daring }\end{array}$ & $82 \%$ & $18 \%$ \\
\hline 4. & $\begin{array}{l}\text { Tugas yang diberikan oleh sekolah tidak } \\
\text { dikerjakan anak saya }\end{array}$ & $85 \%$ & $15 \%$ \\
\hline $\mathbf{5 .}$ & $\begin{array}{l}\text { Saat anak saya tidak mengerjakan, saya } \\
\text { mengerjakan }\end{array}$ & $85 \%$ & $15 \%$ \\
\hline $\mathbf{6}$ & $\begin{array}{l}\text { Saya membutuhkan pendampingan untuk } \\
\text { mendampingi anak saya belajar }\end{array}$ & $100 \%$ & $0 \%$ \\
\hline
\end{tabular}

Pada tabel 1, 80\% seluruh orang tua siswa SDN Nguling I, II dan III menyatakan bahwa anak-anak mereka mengalami kesulitan memahami materi saat pembelajaran daring. $82 \%$ menyatakan bahwa anak-anak sering bermain saat pembelajaran daring berlangsung. 85\% orang tua siswa menyatakan bahwa tugas yang diberikan oleh sekolah tidak dikerjakan dan diperkuat dengan penyataan no 5, 85\% saat anak tidak mengerjakan orang tua lah yang mengerjakan. $100 \%$ orang tua membutuhkan pendampingan untuk anak-anaknya selama pembelajaran daring berlangsung. Hal ini menunjukkan bahwa orang tua memiliki kesadaran tinggi akan pentingnya pendidikan anak-anak terutama saat pandemi berlangsung.

Selanjutnya penulis melakukan analisis kebutuhan dengan melakukan diskusi bersama orang tua. Hasil dari diskusi ini para orang tua membutuhkan pendampingan untuk anak-anak selama pembelajaraan daring melalui SIPUNG. Setelah koordinasi selesai dilakukan penulis membuat proposal mini yang akan digunakan sebagai pedoman dalam implementasi kegiatan sosial SIPUNG. Rancangan kegiatan ini berisi mengenai waktu kegiatan, tempat kegiatan, subyek kegiatan, alat dan bahan yang digunakan selama kegiatan berlangsung. Proposal ini juga sebagai pedoman untuk memberikan gambaran kepada Kepala Sekolah SDN I, II, III dan Kepala Desa saat proses diskusi. Diskusi atau koordinasi dengan kepala sekolah ini dilakukan untuk mendapatkan masukan serta saran terhadap kegiatan yang akan dilakukan kepada siswa SD. Hasil dari diskusi ini adalah seluruh pihak baik dari sekolah dan kepala desa setuju dan sepenuhnya mendukung kegiatan.

\section{Tahap Layanan Pendampingan}

Tahapan implementasi dari kegiatan SIPUNG (Sekolah Ing Kampung) ini dilaksanakan pada tanggal 09 November 2020. Semua siswa berkumpul di tempat salah satu warga yang telah meminjamkan halaman rumahnya sebagai tempat pelaksanaan kegiatan ini. Kegiatan ini diikuti 8 siswa SD yang terdiri dari 6 laki-laki dan 2 perempuan. 
Tahapan ini dibagi menjadi tiga kegiatan yakni, (1) Perkenalan, (2) pembentukan kelompok belajar dan (3) Pendalaman. Adapun tahapan dari kegiatan pendampingan ini adalah sebagai berikut:

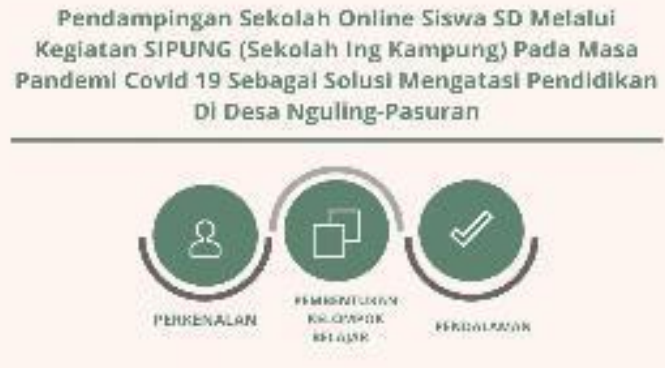

Gambar 2. Rincian Kegiatan

Pada kegiatan perkenalan dalam kegiatan SIPUNG ini penulis membuka dan melakukan perkenalan dengan salam dan memperkenakan dirinya kepada para pelajar yang mengikuti kegiatan. Selanjutnya setiap peserta kegiatan ini diberi kesempatan untuk memperkenalkan dirinya didepan para peserta lainnya. Hal ini dilakukan untuk meningkatkan kepercayaan diri para peserta sekaligus menjalin keakraban para peserta dengan penulis.

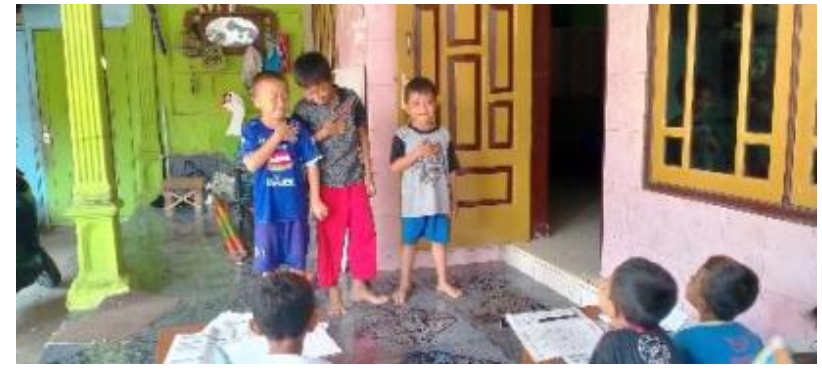

Gambar 3. Kegiatan Perkenalan

Setelah semua siswa telah memperkenalkan diri maka penulis membentuk kelompok belajar. Pada tahap ini para peserta dibagi menjadi 3 kelompok yang masing masing siswa terdiri dari 3 orang dan 2 orang. Setelah itu semua peserta kemudian mengerjakan tugas-tugas sekolah yang diberikan oleh guru selama pembelajaran online.

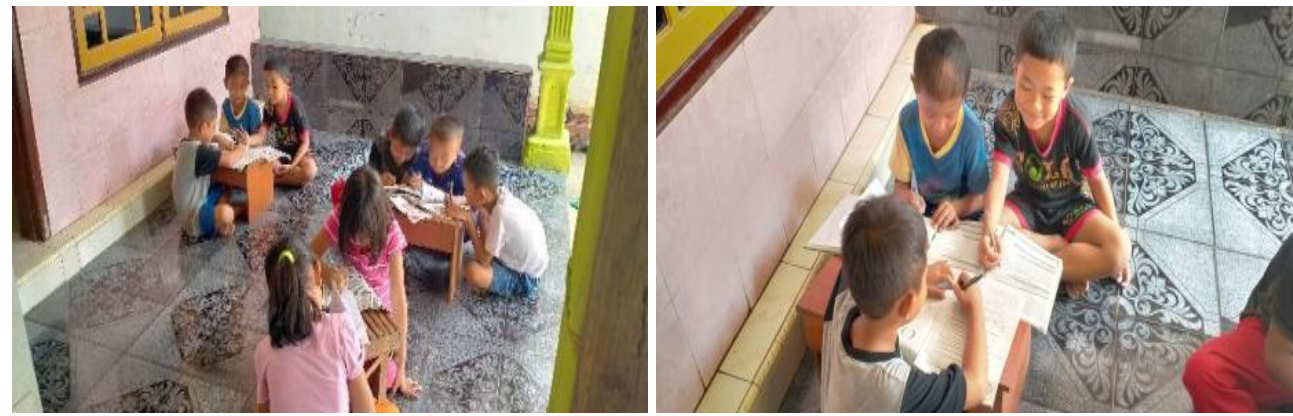




\section{Gambar 4. Kegiatan Pembentukan Kelompok}

Selanjutnya adalah tahap pendalaman. Pada tahap ini penulis menuju meja kelompok untuk mengecek dan melihat hasil yang telah dikerjakan oleh peserta. Para peserta juga aktif bertanya mengenai soal-soal yang tidak dimengerti. Di tahap pendalaman ini penulis melakukan diskusi dengan siswa dan membantu menjelaskan secara rinci mengenai kesalahan jawaban yang telah dikerjakan. Tahap ini sangat penting sekali, karna pada tahap ini relasi dan kedekatan antara penulis dan peserta sangat diutamakan guna tersampaikannya materi dengan baik.

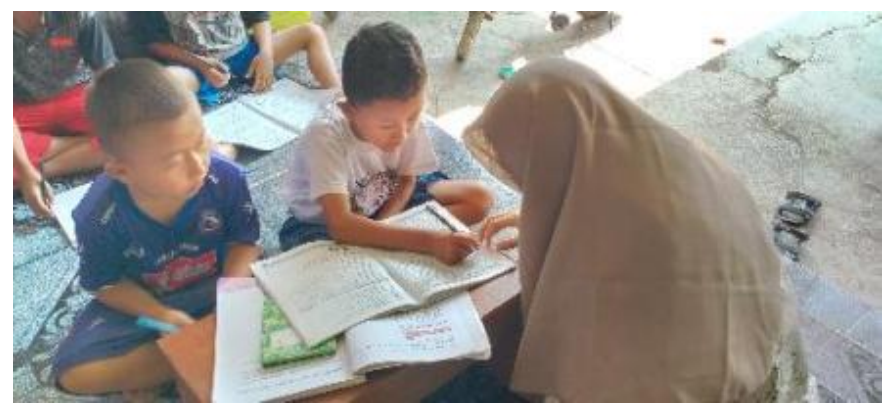

Gambar 5. Kegiatan Pendalaman

\section{Tahap Refleksi Pendampingan}

Tahap akhir dari pendampingan ini adalah refleksi. Refleksi dilakukan setelah kegiatan dilaksanakan oleh para siswa. Refleksi ini berupa penjelasan ulang oleh peserta mengenai apa saja yang mereka dapatkan selama proses kegiatan berlangsung. Disini para peserta menjelaskan mengenai materi baru yang mereka dapatkan dan menceritakan kesalahan-kesalahan mereka dalam menjawab pertanyaan. Berikut ini merupakan gambar dari kegiatan refleksi siswa:

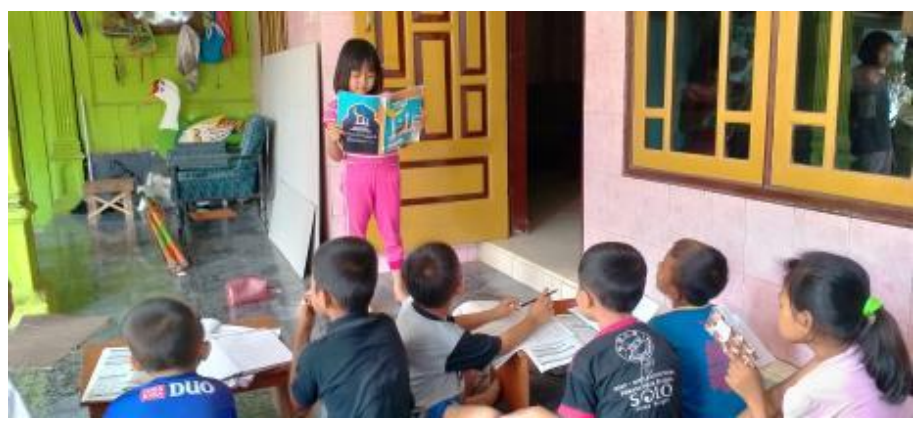

Gambar 6. Tahap Refleksi Siswa

Selain itu refleksi ini juga dilakukan oleh para orang tua siswa dengan menggunakan angket. Angket ini digunakan untuk mengukur seberapa berhasilkah kegiatan pendampingan ini dilaksanakan. Berdasarkan dari data angket yang disebar ditemukan beberapa fakta, yakni tersaji dalam grafik pada Gambar 10. 


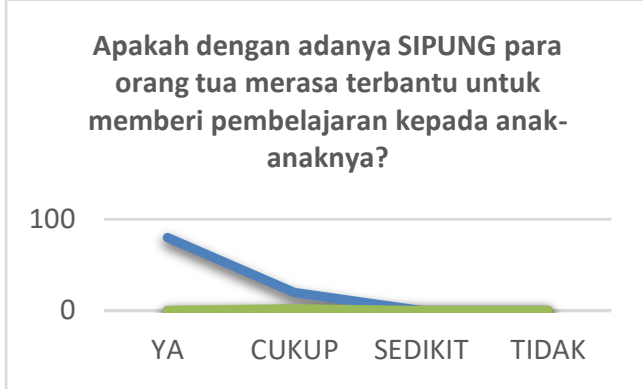

Gambar 7. Tingkat Kemanfaatan Pendampingan Sekolah Online Melalui SIPUNG

Berdasarkan data pada Gambar 10, menunjukkan bahwa para orang tua peserta merasa sangat terbantu dengan adanya pendampingan sekolah online siswa SD melalui kegiatan SIPUNG (Sekolah Ing Kampung). Selanjutnya 70\% orang tua menyatakan kegiatan pendampingan SIPUNG ini berjalan dengan baik, sebagaimana yang dapat dilihat pada Gambar 11.

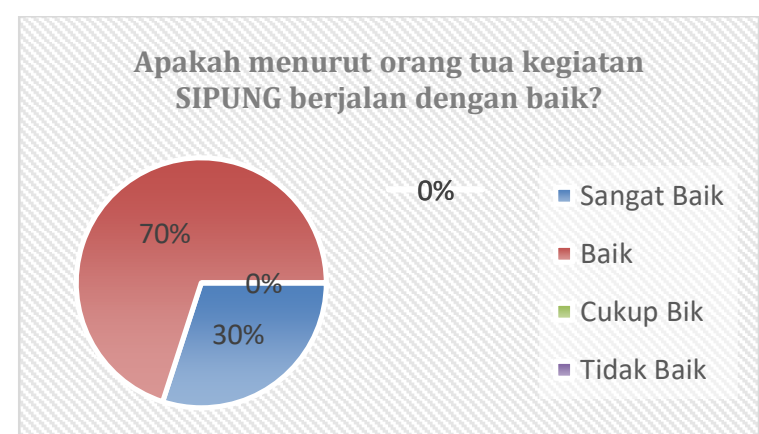

Gambar 8. Tingkat Keberhasilan Pendampingan Sekolah Online Melalui SIPUNG

Berdasarkan analisis dari angket diatas menunjukkan bahwa pendampingan sekolah online Siswa SD melalui kegiatan SIPUNG (Sekolah Ing Kampung) memberikan dampak yang signifikan terhadap siswa dan orang tua selama pembelajaran daring. Dalam hal ini seluruh orang tua siswa sadar akan pentingnya pendampingan pada naka di masa pembelajaran daring.

\section{Diskusi}

Hasil refleksi dari siswa dan angket yang diberikan kepada orang tua siswa menggambrakan bahwa pelaksananaan pendampingan sekolah online melalui SIPUNG dapat memberikan solusi yang tepat terhadap masalah pedidikan yang dilami siswa di SDN I, II dan III Nguling. Adapun dampak dilaksankannnya pendampingan sekolah online melalui SIPUNG ini adalah (1) siswa memahami pentingnya belajar (2) orang tua semakin sadar pentingnya memberikan pendampingan terbaik guna tercapainya keberhasilan pendidikan anak.

Keberhasilan dari pelaksanaan pendampingan ini tidak lepas dari peran antara 
penulis sebagai pendamping dalam pelaksanaan ini sebagaimana yang ada dalam konsep participatory learning yang menjelaskan bahwa keberhasilan dari sebuah kegiataan berasal dari peran aktif seorang pembelajar. Dalam hal ini pembelajar tidak haya menjadi seorang pengajar tapi juga mendapatkan pengalaman sesaat proses pembelajaran berlangsung. ${ }^{13}$ Melalui keberhasilan pendampingan sekolah online SIPUNG ini mampu menciptakan susana belajar yang lebih baik sehingga siswa dapat memahami materi pelajaran di sekolah lebih baik.

Berdasarkan hasil pelakasanaan pendampingan sekolah online melalui SIPUNG ini yang dilakukan oleh penulis disimpulkan bahwa dengan menggunakan metode service learning di tengah pandemi COVID-19 adalah salah satu pelayanan yang bisa diberikan dalam membantu siswa dalam menghadapi permasalahan khususnya untuk kebutuhan pendampingan selama pembelajaran online. Kegiatan pengabdian ini merupakan bentuk pengaplikasian ilmu yang diperoleh di dalam perkuliahan kepada masyarakat dan sebagai aktualisasi untuk berkarya serta bermanfaat bagi lingkungan sekitar dalam melaksanakan salah satu Tridaharma perguruan tinggi yakni pengabdian masyarakat. Kegiatan dengan metode service learning juga merupakan bentuk dari filosofi belajar yakni mahasiswa mampu memahami nilai-nilai yang ada di perkuliahan dan menerapkannya kepada orang lain atau masyarakat untuk memberikan nilai tambah masyarakat itu sendiri. ${ }^{14}$

\section{Simpulan}

Program pengabdian kepada masyarakat melalui pendampingan sekolah online SIPUNG yang dilaksanakan ditengah pandemi COVID-19 ini merupakan salah satu solusi yang tepat digunakan untuk mengatasi masalah pendidikan di Desa Nguling-Pasuruan. Pada pelaksanaan pendampingan ini terdapat tiga tahapan yang diberikan kepada siswa: (1) Perkenalan, (2) Pembentukan Kelompok Belajar, dan (3) Pemahaman. Dalam rangka untuk memecahkan permasalahan yang dialami oleh siswa dalam pembelajaran online ini dengan dilaksanakanya program pengabdian terbukti dapat memperbaiki kualitas pemahaman siswa, pemahaman pentingnya belajar dan kesadaran orang tua akan pendampingan anak di masa pembelajaran daring. Berdasarkan hasil dari program pendampingan ini maka direkomendasikan sebagai berikut: (1) perlu adanya tindak lanjut dari pemerintah ataupun organisasi masyarakat seperti Karang Taruna, PKK dan lainnya guna menjalankan kegiatan ini secara rutin untuk menuntaskan masalah

13 Ilmi Zajuli Ichsan et al., "Covid-19 Dan E-Learning: Perubahan Strategi Pembelajaran Sains Dan Lingkungan Di SMP," JINoP (Jurnal Inovasi Pembelajaran) 6, no. 1 (2020): 50-61; Wahyu Djoko Sulistyo, "Menggugah Sensitivitas Sosial Mahasiswa Melalui Implementasi Praksis Sosial," Jurnal Sosiologi Pendidikan Humanis 4, no. 1 (2019).

14 Irene Nusanti, "Strategi Service Learning Sebuah Kajian Untuk Mengembangkan Kegiatan Pembelajaran," Jurnal Pendidikan dan Kebudayaan 20, no. 2 (2014): 251-260; Alexander W. Astin et al., "How Service Learning Affects Students" (2000). 
pendidikan, (2) perlu adanya koordinasi antara Sekolah Dasar dan orang tua untuk meningkatkat dan melibatkan peran seorang pendamping belajar bagi anak guna tercapainya kualitas pendidikan yang lebih baik.

\section{Pengakuan}

Diucapkan terimakasih yang sebesar-besarnya kepada seluruh pihak yang telah terlibat dalam kegiatan pengabdian kepada masyarakat yaitu Kepala Desa Nguling, Kepala Sekolah dan Guru Kelas SDN I, II dan III di Desa Nguling, Oang Tua Siswa dan Siswa SDN I, II dan III di Desa Nguling Kabupaten Pasuruan. Penulis mengucapkan terimakasih atas partisipasi aktif dari seluruh pihak sehingga program pengabdian kepada masyarakat ini dapat berjalan denga baik dan sebagaimana sesuai dengan tujuan.

\section{Referensi}

Aji, Rizqon Halal Syah. "Dampak COVID-19 Pada Pendidikan Di Indonesia: Sekolah, Keterampilan, Dan Proses Pembelajaran." Salam: Jurnal Sosial dan Budaya Syari.(7) 5 (2020): 395-402.

Astin, Alexander W., Lori J. Vogelgesang, Elaine K. Ikeda, and Jennifer A. Yee. "How Service Learning Affects Students" (2000).

Bahasoan, Awal Nopriyanto, Wulan Ayuandiani, Muhammad Mukhram, and Aswar Rahmat. "Effectiveness of Online Learning in Pandemic COVID-19." International Journal of Science, Technology \& Management 1, no. 2 (2020): 100-106.

Batubara, Beby Masitho. "The Problems of the World of Education in the Middle of the Covid-19 Pandemic." Budapest International Research and Critics Institute (BIRCIJournal): Humanities and Social Sciences 4, no. 1 (2021): 450-457.

Felten, Peter, and Patti H. Clayton. "Service-Learning." New directions for teaching and learning 2011, no. 128 (2011): 75-84.

Handayani, Tri, Hariyani Nur Khasanah, and Rolisda Yoshinta. "Pendampingan Belajar Di Rumah Bagi Siswa Sekolah Dasar Terdampak Covid-19." ABDIPRAJA Uurnal Pengabdian kepada Masyarakat) 1, no. 1 (2020): 107-115.

Henry, Arley, and Teresa Shellenbarger. "To Zoom or Not to Zoom? Choosing a Videoconferencing Platform." Nurse Author \& Editor 30, no. 4 (2020): 3.

Ichsan, Ilmi Zajuli, Henita Rahmayanti, Agung Purwanto, Diana Vivanti Sigit, Edi Kurniawan, Aryani Kadarwati Dewi, Nina Wirdianti, Farah Muthi Hermawati, and Giry Marhento. "Covid-19 Dan E-Learning: Perubahan Strategi Pembelajaran Sains Dan Lingkungan Di SMP." JINoP (Jurnal Inovasi Pembelajaran) 6, no. 1 (2020): 50- 
61.

INDONESIA, PRESIDEN REPUBLIK. “Undang-Undang Republik Indonesia Nomor 20 Tahun 2003 Tentang Sistem Pendidikan Nasional” (2006).

KEBUDAYAAN, MENTERI PENDIDIKAN DAN, and REPUBLIK INDONESIA. "Surat Edaran Nomor 4 Tahun 2020 Tentang Pelaksanaan Kebijakan Pendidikan Dalam Masa Darurat Penyebaran Coronavirus Disease (COVID-19)" (2020).

Marbun, Stefanus M., S. Th, and M. PdK. Psikologi Pendidikan. Uwais Inspirasi Indonesia, 2018.

Muhardi, Muhardi. "Kontribusi Pendidikan Dalam Meningkatkan Kualitas Bangsa Indonesia." Mimbar: Jurnal Sosial dan Pembangunan 20, no. 4 (2004): 478-492.

Mustakim, Mustakim. "Efektivitas Pembelajaran Daring Menggunakan Media Online Selama Pandemi Covid-19 Pada Mata Pelajaran Matematika." Al asma: Journal of Islamic Education 2, no. 1 (2020): 1-12.

Nusanti, Irene. "Strategi Service Learning Sebuah Kajian Untuk Mengembangkan Kegiatan Pembelajaran." Jurnal Pendidikan dan Kebudayaan 20, no. 2 (2014): 251260.

pasuruan, pemkab. "Kabupaten Pasuruan Kembali Berstatus Zona Oranye Covid-19 | Situs Resmi Pemerintah Kabupaten Pasuruan." Last modified 2020. Accessed June 8, 2021. https://www.pasuruankab.go.id/berita-5943-kabupaten-pasuruankembali-berstatus-zona-oranye-covid-19.html.

Setyowati, Endah, and Alviani Permata. "Service Learning: Mengintegrasikan Tujuan Akademik Dan Pendidikan Karakter Peserta Didik Melalui Pengabdian Kepada Masyarakat." Bakti Budaya: Jurnal Pengabdian kepada Masyarakat 1, no. 2 (2018): 143.

Simanihuruk, Lidia, Janner Simarmata, Acai Sudirman, M. Said Hasibuan, Meilani Safitri, Oris Krianto Sulaiman, Rahmi Ramadhani, and Syafrida Hafni Sahir. E-Learning: Implementasi, Strategi Dan Inovasinya. Yayasan Kita Menulis, 2019.

Sulistyo, Wahyu Djoko. "Menggugah Sensitivitas Sosial Mahasiswa Melalui Implementasi Praksis Sosial.” Jurnal Sosiologi Pendidikan Humanis 4, no. 1 (2019).

Wajdi, Muh Barid Nizarudin, M. Burhanuddin Ubaidillah, Sri Mulyani, Khoirul Anwar, Lailatul Istiqomah, Fauziyah Rahmawati, Sholihatul Atik Hikmawati, Diah Retno Ningsih, and Hasan Syaiful Rizal. "Pendampingan Redesign Pembelajaran Masa Pandemi Covid-19 Bagi Tenaga Pendidik Di Lembaga Pendidikan Berbasis Pesantren Di Jawa Timur." Engagement: Jurnal Pengabdian Kepada Masyarakat 4, no. 1 (2020): 266-277. 